This item was submitted to Loughborough's Research Repository by the author.

Items in Figshare are protected by copyright, with all rights reserved, unless otherwise indicated.

\title{
Shucks, we've got glamour girls too! Gertrude Stein, Bennett Cerf and the culture of celebrity
}

PLEASE CITE THE PUBLISHED VERSION

http://dx.doi.org/10.2979/jmodelite.39.1.149

\section{PUBLISHER}

(C) Trustees of Indiana University

\section{VERSION}

AM (Accepted Manuscript)

\section{PUBLISHER STATEMENT}

This work is made available according to the conditions of the Creative Commons Attribution-NonCommercialNoDerivatives 4.0 International (CC BY-NC-ND 4.0) licence. Full details of this licence are available at: https://creativecommons.org/licenses/by-nc-nd/4.0/

\section{LICENCE}

CC BY-NC-ND 4.0

\section{REPOSITORY RECORD}

Jaillant, Lise. 2019. "Shucks, We've Got Glamour Girls Too! Gertrude Stein, Bennett Cerf and the Culture of Celebrity”. figshare. https://hdl.handle.net/2134/20568. 
Shucks, we've got glamour girls too! Gertrude Stein, Bennett Cerf and the Culture of Celebrity

Lise Jaillant

[This is the author's version. The final version was published in Journal of Modern Literature 39.1 (2015): 149-69]

Abstract: September 1933 was a turning point in Gertrude Stein's career. That month, Alfred Harcourt published The Autobiography of Alice B. Toklas and Bennett Cerf issued Three Lives in the Modern Library, a cheap series of reprints marketed as "the world's best books." While most scholars have linked Stein's celebrity to the Autobiography, the publication of her experimental texts by the Modern Library and Random House has been largely overlooked. This article is organized around two central claims. First, it shows that unlike Alfred Harcourt, Cerf adopted a long-term strategy by publishing Stein's difficult writings, as well as her more accessible texts. Second, from 1934, Cerf used new media to position Stein as an atypical literary star. After the publication of Three Lives, he organized her tour in America and promoted her using his experience of the Hollywood industry. Blurring the boundaries between print and broadcasting, Cerf created a unique strategy for marketing Stein, a strategy that enabled her to stand out in a crowded literary marketplace.

Keywords: Gertrude Stein / Bennett Cerf / Celebrity / Publishers and Publishing. 
On 3 September 1933, an advertisement for The Autobiography of Alice B. Toklas showed a picture of Gertrude Stein, with a list of "People in the Book" displayed over two columns. Famous painters (Pablo Picasso, Henri Matisse), writers (Ernest Hemingway, Sherwood Anderson), and other artists (including Josephine Baker, Jean Cocteau and Carl Van Vechten) were presented as "the people that crowd [Stein's] atelier" in Paris. The publisher Alfred Harcourt reassured anxious readers that Stein's style was now "lucid, artless, delightful" (The Autobiography). In the same issue of the New York Times, a short announcement declared that Stein's Three Lives would be published in September in the Modern Library, a cheap series of reprints marketed as "the world's best books" ("Books and Authors"). ${ }^{1}$

William Bradley, Stein's literary agent, had initially approached not the Modern Library, but Alfred Harcourt himself. As Catherine Turner points out, "Bradley urged Harcourt to buy sheets of The Making of Americans from John Lane, buy the plates of Three Lives from Albert and Charles Boni, distribute Toklas's Plain Editions, and publish the libretto to Four Saints in Three Acts in conjunction with the opening of this opera in January 1934" (121). Harcourt reluctantly agreed to publish The Making of Americans in an abridged version, but refused to take on Stein's other experimental writings. Bennett Cerf, the co-owner of the Modern Library and Random House, was much more eager to publish difficult texts by famous modernist writers. ${ }^{2}$ In the late 1920 s, at the time when James Joyce and Virginia Woolf had become well-known names in America, ${ }^{3}$ the Modern Library reprinted Dubliners, A Portrait of the Artist as a Young Man and Mrs Dalloway, and sold them for only ninety-five cents. Although Cerf repeatedly claimed that the Modern Library only selected texts that had been "a big success in the original higher priced edition" (BC to Tom Coward, 15 Oct. 1942), the first edition of Three Lives, published by the Grafton Press in 1909, sold fewer than 100 of the 500 bound copies in the six months following its publication (Conrad 216). In 1927, Albert and Charles Boni published a new edition of the book, and sold it for \$2. Six years later, the Modern Library edition of Three Lives appeared at the same time as The Autobiography of Alice B. Toklas. Between 1909 and 1933, Three Lives made the transition from a vanity press (the Grafton Press), to a small press that spent few resources on advertising and distribution (the 
Boni Brothers' imprint), to a larger publishing enterprise well advertised and distributed across the country and abroad (the Modern Library).

While scholars and commentators have presented The Autobiography of Alice B. Toklas as a turning point in Stein's career, the publication of her experimental texts by the Modern Library and Random House has been largely overlooked. Whereas Harcourt soon let the Autobiography go out of print, Cerf adopted a long-term strategy by publishing Stein's esoteric writings, as well as her more accessible texts. In this article, I take the Modern Library edition of Three Lives as an example of a difficult text that reached a wide audience thanks to Cerf. I then turn to the period immediately following the publication of Three Lives. From 1934, Cerf used his experience of the Hollywood industry to reinforce Stein's image as an atypical literary star and to broaden its impact. My point is not that Cerf created Stein's celebrity (she was already famous when he started publishing her texts). Instead, I want to show that Cerf widened the appeal of Stein's difficult works, which had so far been restricted to a tiny coterie of readers. Thanks to Cerf, Stein was able to reach an audience that listened to the radio and went to movie theaters but rarely read books. Blurring the boundaries between print and broadcasting, Cerf created a unique strategy for marketing Stein, a strategy that enabled her to stand out in a crowded literary marketplace.

Cerf later became a celebrity himself. His brief marriage to the Hollywood actress Sylvia Sidney in 1935, his radio program "Books are Bullets" during the Second World War, his bestselling joke books starting with Try and Stop Me (1944) and most importantly, his participation in the television show What's My Line? in the 1950s and 1960s transformed him into a household name. Cerf's joviality and sense of humor had not yet made him famous in the early 1930s, but these personal characteristics helped him attract the attention of journalists to promote Random House authors such as Stein, James Joyce and William Faulkner.

Although several studies have explored the relationship between modernism and celebrity, the role of publishers in promoting modernist stars is seldom mentioned. In a recent survey of the scholarship in this field, Rod Rosenquist has distinguished between the self-fashioning efforts of modernist writers on 
the one hand, and "the mediation of promotional networks and institutions and the interests of the public in consuming celebrity" on the other hand (446). Aaron Jaffe, Loren Glass and Jonathan Goldman have focused on authorial presentation and promotion, rather than on the "communications circuit" that runs from author to publisher, printer, bookseller and reader. ${ }^{4}$ Other scholars have paid more attention to the role of institutions that mediated between the celebrated writer and the public. In Women, Celebrity, and Literary Culture between the Wars (2007), Faye Hammill sheds light on the "particular magazines, publishing houses, literary prizes, theaters, hotels, and Hollywood studios" that structured the authors' “public images and professional lives" (2). Similarly, Karen Leick’s Gertrude Stein and the Making of an American Celebrity (2009) examines the changes in the literary marketplace that enabled the dissemination of high modernism to mainstream America (3). Leick shows that, although Stein was already a well-known figure in the 1920s, her lecture tour transformed her into an A-list celebrity. As Leick rightly points out, Bennett Cerf was instrumental in boosting Stein's popularity, through two strategic promotional channels: the radio and the film (166). However, Leick gives little details on Cerf's personal background and relationship with Hollywood. In contrast, my essay draws on little-known archival documents to highlight Cerf's fascination with celebrity and his extensive network of contacts in the film industry, which allowed him to use marketing strategies that were highly unusual at the time.

\section{The Publication of Three Lives in the Modern Library (1933)}

Cerf was convinced that with the right strategy, even seeming non-commercial writings could find a market. In May 1933, when the Atlantic Monthly began serializing The Autobiography of Alice B. Toklas, Cerf asked Albert Boni if the plates for Three Lives would fit the Modern Library edition (BC to

Boni, 11 May 1933). ${ }^{5}$ At least two people claimed to have encouraged Cerf and his colleagues' interest in Stein. The first one was Lindley Williams Hubbell, a reference librarian at the New York Public Library. On 11 May, he informed Stein that, after reading his review of the Plain Edition, his agent Ben Wasson spoke to an editor at the Modern Library (presumably Cerf). After some hesitation, the Modern Library expressed interest in reprinting Three Lives. "May I venture the opinion," wrote Hubbell, "that, no matter 
what your other plans are, it would be a very good thing to have the Modern Library print Three Lives? You have no idea how widely read that library is in this country, and after all why shouldn't you be a great writer during your life time if it happens that way?" (Hubbell to GS, 11 May 1933). ${ }^{6}$ Here, Hubbell emphasized both the commercial success of the Modern Library, and its ability to transform works into classics (an argument that must have appealed to Stein, who had long dreamed of being recognized as a “great writer").

Carl Van Vechten, whose novel Peter Whiffle had appeared in the Modern Library four years earlier, was also instrumental in the reprinting of Three Lives. Van Vechten went on to write the introduction to the book, a choice that delighted Stein (GS to Van Vechten, [July 1933?]). ${ }^{7}$ In July, a check of $\$ 400$ was sent to Stein's agent, corresponding to the advance royalty $(\$ 300)$ and the use of the plates for Three Lives (\$100) (Bradley to BC, 20 July 1933). Since the Modern Library paid a royalty of 5 cents per copy (BC to GS, 16 May 1933), the advance corresponded to 6,000 copies. In an effort to keep the royalty rate low, Cerf told William Bradley that "Miss Stein is still caviar for the masses, and ... we cannot expect a very tremendous sale for the book" (16 June 1933). But his aim was clearly to reach thousands of readers. Thanks to the Modern Library, Stein's most experimental writings were now sold to a mainstream audience in America and elsewhere.

Stein was pleased with Van Vechten's introduction, and with the physical format of the Modern Library edition. Shortly after receiving several copies of her books, she wrote to Van Vechten: “Three Lives has just come and it is a darling little blue book and a darling not at all blue introduction but a sweet one and a rosy one and I am as happy as can be, happier than I can tell you" (GS to Van Vechten, 11 Oct. 1933). She also thanked Cerf for the books and again commented on the "charming" blue binding, which was made of stiff balloon cloth. ${ }^{8}$ The dust jacket of the Modern Library edition had been designed by Ernest Reichl, a German-born artist who came to the USA in 1926 (Drew and Sternberger 31). The three blue rectangles inscribed with the title Three Lives in bold type gave a strikingly modern aspect to the book. Reichl also created the dust jacket of the pivotal Random House edition of Ulysses, released only four months after Three Lives (Figure 1). As Edward Bishop has argued, the Random House wrapper 
made the book resemble a "work of avant-garde art to display" - and the same could be said of Three Lives, a book that looked like "the latest thing from Europe" despite its cheap price (34-35). Donald Klopfer, who was in charge of book production at Random House, later asked Reichl to design the wrapper of Stein's Lectures in America: "I would suggest a cover comparable to the ULYSSES cover which was so successful" (Klopfer to Reichl, 4 Feb. 1935). The association with Reichl strengthened the Modern Library and Random House's reputation as innovative publishing enterprises, committed to the diffusion of high modernism.
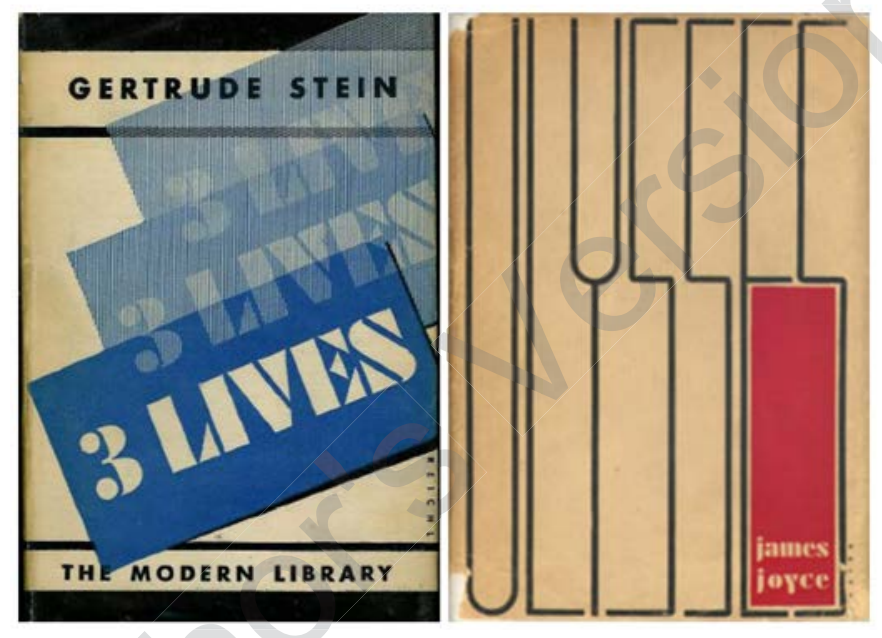

Figure 1: Dust Jackets, Modern Library ed. of Three Lives and Random House ed. of Ulysses.

\section{Design by Ernest Reichl.}

Cerf oversaw all marketing and advertising decisions, and he was responsible for the text on the inside flap of the dust jacket, which confidently presents Stein as a popular rather than an elitist writer:

Three Lives, says the Saturday Review, "stands as a massive doorpost in the entrance to the latest and best in American literature." The book has had a curious history. Readers who were baffled by Gertrude Stein's later work were afraid to tackle it. Twice it was allowed to go out of print altogether. Each time, however, enthusiastic admirers created 
sufficient demand to warrant new printings. The emphatic success of Miss Stein's autobiography must finally win for this splendid book the wide audience that is its due. (emphasis added)

Three Lives was thus described as a book than everybody could understand, including ordinary readers "baffled by Gertrude Stein's later work."

Even before the publication of Three Lives, Cerf started an ambitious advertising campaign, a campaign that Stein followed closely. "I have lots of clippings," wrote Stein to Bradley ([Aug.] 1933), "they are doing a big publicity for it." Like other Modern Library titles, Three Lives was advertised as both entertaining and distinguished. In one advertisement in the New Republic, Stein's text appeared at the top of a list of Modern Library books - "books chosen not only for their ability to entertain and delight, but books that are evidencing the trend and development of the modern mind" (Modern Library (a), emphasis in the original). The release of Three Lives was tied to The Autobiography of Alice B. Toklas, reviewed by Edmund Wilson a few pages before. Wilson presented the Autobiography as an important literary event: "It is the only thing she has published since Three Lives which is from the ordinary point of view easily readable" (247). Ordinary readers were therefore nudged to buy not only the Autobiography, but also the cheap edition of Three Lives. Another advertisement linked the Modern Library to summer reading: "Sick of Sappy Stories? Why not read some really good books this summer... in the convenient, inexpensive MODERN LIBRARY" (Modern Library (b)). The picture of a suitcase packed with Modern Library books reinforced this association between travel, leisure, and pleasurable reading. Gertrude Stein was one of the few women writers on the Modern Library list, and Three Lives (\#211 in the series) was listed between Anatole France's Penguin Island (\#210) and Lytton Strachey's Eminent Victorians (\#212). An insert at the center of the advertisement featured the Hollywood actress Frances Dee, "enjoying the complete Modern Library edition" of Somerset Maugham's Of Human Bondage. The twenty-four-year-old Dee, known for her lead roles in Playboy of Paris and An American Tragedy, had just appeared in the film adapted from Maugham's novel. This early 
example of movie tie-in shows that the Modern Library was increasingly marketed as a glamorous series that participated in the celebrity culture of the 1930s.

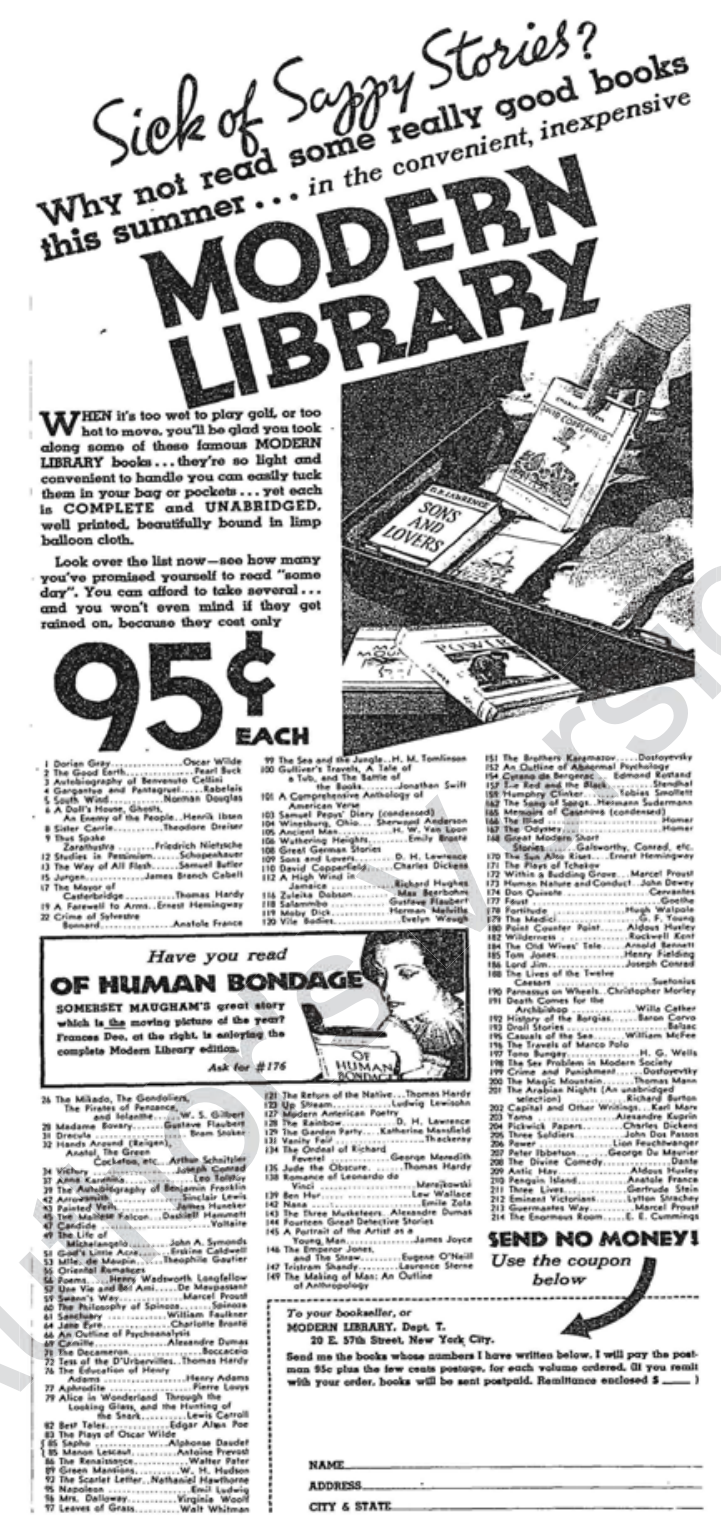

Figure 2: Advertisement for the Modern Library, New York Times 5 Aug. 1934: BR13.

The publication of Three Lives in the Modern Library was frequently mentioned in reviews and articles on Gertrude Stein. In September 1933, Time magazine chose Stein for its cover. "She has moved from the legendary borders of literature into the very marketplace, to face in person a large audience of men-in-the-street," declared the article ("Books: Stem's Way"). Stein was now supported by large-scale 
publishing enterprises, such as the Literary Guild (which had just selected The Autobiography of Alice B. Toklas) and the Modern Library, "whose editors' ears are close to the ground." The Time reviewer implied that the Modern Library had responded to a growing demand: many Americans had heard of Stein, and wanted to buy her books in easily available editions. In the Chicago Daily Tribune, Fanny Butcher similarly described Three Lives as "one of the great books of our day" whose audience had so far been too limited (“Gertrude Stein Writes a Book in Simple Style”). ${ }^{9}$ Since the Modern Library had long been popular among students, the Daily Princetonian also announced the publication of Three Lives: "Carl Van Vechten contributes the extraordinarily friendly, even for Gertrude Stein, introduction, in which he tells much about her and about the three short stories in this inexpensive reprint edition" (28 Sept. 1933: 2). For many students, at Princeton University and elsewhere, the Modern Library offered an opportunity to keep abreast of modern literature without spending a lot of money on books. Ordinary readers in Toledo, Ohio were also encouraged to read Three Lives. In a Toledo News-Bee review entitled "Life Among the Nudists and An Early Work by Gertrude Stein Considered," Allen Saunders described his “curious experience" reading Stein's three novelettes:

The monochrome, repetitious style, while it fairly exudes sincerity, will put you to sleep, unless you're fairly wide awake. But just when you're ready to toss the book aside and cry "Pish-tosh!," out pops a line that, for depth of perception and power of composition, is dazzlingly brilliant. What seemed pewter, you discover, is really platinum. So, if you finish the story of "The Good Anna," wherein the complicatedly simple friendships of a German house-keeper are analyzed, you'll probably continue thru "Melanctha," the troubled spiritual and romantic awakening of a Negro girl, and thru "The Gentle Lena," my choice of the three, in which a marriage is arranged for an immigrant girl, who awaits the event with stolid peasant submissiveness. ("Life Among the Nudists and An Early Work by Gertrude Stein Considered") ${ }^{10}$ 
Here, Saunders offered advice on how to read Stein's difficult writings. He mapped a reading process characterized by strong emotional reactions, from perplexity and discouragement, to gradual admiration and even pleasure. In doing so, he anticipates Bennett Cerf's marketing strategy to explain "How to Enjoy James Joyce's great novel Ulysses." ${ }^{11}$ In the early 1930s, reviewers, publishers, and other cultural intermediaries developed pedagogical tools to teach high modernism to a large audience of aspirational readers - thus opening new markets for complex works.

The Modern Library did allow Stein to reach the broad audience she had been expecting for a long time. In October 1933, Cerf informed her that Three Lives "is proving to be a tremendous success." Less than one month after its publication, the book had already sold 4,500 copies (BC to GS, 23 Oct. 1933). The department store Macy and Co. alone bought 1,300 copies, a number that Cerf found “astonishing." Since Three Lives had proved a commercial success, Cerf offered to publish The Making of Americans (not knowing that Harcourt already planned to issue the book in an abridged version). ${ }^{12}$ Shortly after receiving Cerf's letter, Stein wrote to her friend Carl Van Vechten and his wife: she was thrilled to learn that "Three Lives is selling like hot cakes" and she wanted some of her other works to appear in the Modern Library. The volume of reprints she had in mind would include texts mentioned in the Autobiography but difficult to find in America: "The Tender Buttons, the things in Rogue, Flowers of friendship, the portrait [of] Mabel Dodge, Four Saints Mildred's Thoughts, and enough more to make a nice fat volume" (GS to the Van Vechtens, 4 Nov. 1933). Cerf's response was not very encouraging (BC to GS, 21 Nov. 1933). He had little interest in Stein's earlier work, apart from her often-discussed magnum opus, The Making of Americans. Having just published Three Lives in the Modern Library, he felt that the market for a reprint of Stein's earlier writings would be too limited to justify the investment. Although Cerf promised Stein that he would reconsider the idea in a few months, the project did not come to light until 1946, when Random House published Selected Writings of Gertrude Stein (the volume, edited by Van Vechten, appeared as a Modern Library reprint in 1962, nearly three decades after Stein's suggestion). Cerf's lack of enthusiasm is coherent with his vision that Modern Library books should sell to a large audience over a long period of time. Although Cerf was cautious not to saturate the market for 
Stein's work with cheap Modern Library books, he was ready to publish her new experimental writings in trade editions under the Random House imprint. Unlike reprints, new books were more likely to be reviewed in literary magazines and mainstream press, and to sell in respectable quantities. ${ }^{13}$

Contrary to Cerf, Harcourt was never confident he could find an audience for Stein's difficult works. For Harcourt and his colleagues, Stein was marketable as long as she continued writing gossips about the Parisian artistic milieu. "As publishers, we naturally want to secure the widest possible reading for Miss Stein's books, to keep and extend her audience," wrote Donald Brace (Harcourt's partner) to William Bradley (11 May 1934). "We want in general to confine ourselves to publishing what may be called Miss Stein's more open books." Brace and Harcourt saw The Autobiography of Alice B. Toklas as a literary coup rather than a modern classic that would sell for years. In 1936, Harcourt announced his intention to let the autobiography go out of print. Cerf thought this was "a very short-sighted" strategy and bought all rights and existing stock of the book (BC to Wilder, 19 Aug. 1936).

In late 1933, at the time when Harcourt was still Stein's main publisher in America, Cerf had started to change the way she was perceived. For Cerf, Stein's success relied not only on her memoirs and other "readable" texts but also on her more difficult writings. Without The Autobiography of Alice B. Toklas, Stein would have remained a coterie writer exiled in Paris, far from the interest of mainstream America. But without Three Lives and her other experimental texts, Stein risked appearing as a shallow society hostess - another Ottoline Morrell rather than a Virginia Woolf.

Stein later commented on her publishers' different strategies in Everybody's Autobiography. Whereas Bradley had told her that "no necessary relation exists between the two categories of your work and that to seek to create a purely artificial one for your publisher would be fantastic, if not fatal" (Bradley to GS, 19 July 1934), Cerf was willing to create such a connection between her "closed" and "open" books. Stein still had regrets about the abridged edition of The Making of Americans, and wished it had been published complete in the Modern Library instead. "Harcourt Brace did not really want to print the Making of Americans, they made him, but Bennett Cerf did," she wrote (ch. 3). For Stein, Cerf was the first commercial publisher to understand the importance of her experimental works. 


\section{Stein's American Tour (Fall 1934 - Winter 1935)}

Despite the differences between Harcourt's and Cerf's marketing strategies, scholars have presented both publishers as equally uneasy with Stein's less commercial writings. Bryce Conrad thus argues that Stein settled for a "'promotional' package" orchestrated by Cerf and Van Vechten "to accompany a Stein lecture tour of the United States in the fall and winter of 1934-35" (Conrad 226-27). According to Conrad, this package included the publication of Four Saints in Three Acts (Stein's libretto for the opera by composer Virgil Thomson) as well as Portraits and Prayers and Lectures in America. In fact, at the time when Random House released Four Saints in Three Acts, Stein had not yet accepted to do a lecture tour. Five months after the inclusion of Three Lives in the Modern Library, Cerf was again publishing a difficult text by Stein without any certitude that she would come to America to help with the promotion.

With the publication of Four Saints in Three Acts, one month after Joyce's Ulysses, the newly created Random House positioned itself as a major publisher of modernist literature. However, Cerf was careful to market Stein's and Joyce's work not as "highbrow," but as readable and pleasurable. Booksellers were reminded that "a supply of reprints of the double-page advertisement 'How to Enjoy James Joyce's Ulysses"” was available for distribution to customers (Klopfer to Rosenberg, 7 Feb. 1934). This advertising campaign, designed by Cerf and Aaron Sussman, contributed to the commercial success of the book. ${ }^{14}$ Ulysses was sold not only in bookstores, but also among magazines in various outfits. Indeed, Cerf managed to sell 5,000 copies of Ulysses to the American News Company, the number one distributor of books among stationary stores (Reminiscences, 23 Oct. 1967). “A best seller everywhere! Now 35th thousand," declared one advertisement (Random House). Similarly, Random House sent out press releases announcing the commercial success of Stein's libretto: two days after its release, the first printing of 1,000 copies had already been exhausted ("Book Notes"). In April 1934, Random House ordered a fourth printing of the book, putting the total number of printed copies to 4,000 (J. J. Little and Ives Co. to Harper, 7 April 1934). Although these numbers were modest compared to Ulysses, Cerf had 
proved that one could "ma[k]e money on Gertrude." ${ }^{15}$ With some sixty performances in six weeks, Four Saints in Three Acts became the longest-running opera in Broadway history (Hitchcock and Fussell xiii).

Once Stein confirmed that she would come to America, ${ }^{16}$ Cerf started working on a large-scale publicity campaign. And for the first time, he used new media to broaden Stein's impact. He confidently told his sale representative: "Gertrude Stein arrives in New York on October 24th and will make the front page of every New York paper" (BC to Rosenberg, 16 Oct. 1934). The "media blitz" mentioned by Conrad did not appear magically (228): it was Cerf who acted as a public relations man to maximize media interest. Cerf later recalled that "it was a front-page story . . ; the papers . . all sent down their cleverest reporters to meet Gertrude Stein ... Gertrude proceeded to handle this bunch of fresh photographers and newsmen as the master she was. She was the publicity hound of the world - was simply great. She could have been a tremendous hit in show business" (Reminiscences, 23 Oct. 1967). Here, Stein is presented as a star with a natural talent for attracting attention. Like Hollywood executives, Cerf stayed in the shadow so that media attention seemed the result of the star's charisma rather than the product of the star machine. It is also probable that Cerf knew about Stein's fierce opposition to lecture bureaus and PR professionals, an issue that contributed to the breakdown of her relationship with William Bradley. Two years later, when one editor at Houghton Mifflin was planning to bring the British writer Edith Sitwell over to America, he asked Donald Klopfer for the name of Stein's publicity agent. Klopfer told him she had none: "That gal is just news" (Klopfer to Warren, 29 June 1936). ${ }^{17}$ The myth of a naturally charismatic Stein has been influential to this day. ${ }^{18}$

Cerf used not only print, but also broadcasting to boost Stein's celebrity. On the evening of Stein's arrival in New York, the movie company Pathé recorded a short film in her suite at the Algonquin Hotel, and the film was then shown in theaters across the country. In this recording, Stein explicitly presented her writings as fun and enjoyable. In her lectures, she wanted "to tell so simply that anybody will know it and know it very very well that you can enjoy the things I have been writing" (Burns and Dydo 351). ${ }^{19}$ In November 1934, Cerf also organized a coast-to-coast radio broadcast. Stein was interviewed by NBC reporter William Lundell on WJZ and NET radio. Cerf later said: 
We went to the studio, and Miriam Hopkins came with us ... I started the radio interview by remarking, "Gertrude Stein, here you are on a coast-to-coast hook-up. This is going to be your chance to explain to the American public what you mean by these writings of yours.” I added, “I'm very proud to be your publisher, Miss Stein, but, as I've always told you, I don't understand very much that you're saying." She replied promptly, "Well, I've always told you, Bennett, you're a very nice boy but you're rather stupid." (Reminiscences, 23 Oct. 1967)

There are several interesting things here. First, we learn that Cerf presented himself as an ordinary reader baffled by Stein's difficult writing style. It was a clever way to side with the audience, who might also be confused. Cerf used the same marketing strategy two years later, when he wrote the blurb for another book by Stein, The Geographical History of America: "I must admit frankly that I do not know what Miss Stein is talking about. I do not even understand the title. I admire Miss Stein tremendously, and I like to publish her books, although most of the time I do not know what she is driving at." ${ }^{20}$ Thanks to this unconventional blurb, Stein's difficult book was widely reviewed. As late as 1941, Cerf continued to take on the role of the puzzled reader. In the blurb for Stein's novel Ida, he wrote: "here it is, presented faithfully to you by a publisher who rarely has the faintest idea of what Miss Stein is talking about, but who admires her from the bottom of his heart for her courage and for her abounding love of humanity and freedom." 21

The second interesting point is that the actress Miriam Hopkins was present at the interview. Cerf first met Hopkins in the early 1920s, when he was working for the publisher Horace Liveright (himself a lover of celebrity). Not yet the famous movie star, Hopkins was already "the center of attention, not because anybody knew who she was, but because she was so attractive" (BC, Reminiscences, c. 1967). By the early 1930s, Cerf had developed an extensive network of contacts in the film industry. ${ }^{22} \mathrm{He}$ was still very close from Hopkins, who had scored her breakthrough in Ernst Lubitsch's Trouble in Paradise 
(1932). Hopkins worked primarily in the movie industry, but she had also appeared in a radio production called "Seventh Heaven," which had been broadcasted on NBC in October (the month before Stein's interview). It is highly probable that Cerf knew some people at NBC through his connection with Hopkins. Cerf understood that there was no gap between different medias: film, radio, and print.

Miriam Hopkins was also mentioned during the interview itself, when Lundell repeated a joke that Cerf had told him earlier:

\begin{abstract}
After the party given in your honor by Random House and the Modern Library, Mr Cerf was going down in the elevator and he talked with the elevator boy. The boy said, "You had a big party." Mr Cerf replied "Yes, we had a lot of celebrities there. How did it strike you?" The boy said, "Well, I only recognize two of them... Miss Stein and Miriam Hopkins, the movie actress.” (Stein, “A Radio Interview” 88)
\end{abstract}

At the time of the interview, Hopkins was near the top of her career, having recently starred in Design for Living with Gary Cooper, and The Story of Temple Drake - the controversial movie adaptation of William Faulkner's Sanctuary, which became a box-office smash (Figure 3). ${ }^{23}$ An avid reader, Hopkins was a favorite among many writers and intellectuals: F. Scott Fitzgerald suggested her for the role of Nicole in Tender is the Night, for example (Fitzgerald to BC, 20 Nov. 1934). Hopkins's celebrity did not intimidate Stein. According to Cerf, his famous author did not hesitate to order Hopkins around: "This amused her having a movie star calling for shoes for her and having her clothes dry-cleaned" (Reminiscences, 23 Oct. 1967). Stein probably knew that even a young and glamorous Hollywood star like Hopkins did not have the same kind of celebrity capital (Hopkins had not yet appeared on the cover of Time magazine, for instance) ${ }^{24}$ Stein was so confident in her own fame that she reportedly told Hopkins: "Miriam, you're a big movie star, and I [am] just a little writer from Paris, but I'll bet you more people recognize me before we get to that restaurant than recognize you" (Reminiscences, 23 Oct. 1967). Hopkins apparently refused to bet, because she knew that Stein was more recognizable. The story was repeated with various 
embellishments in the media. As late as 1940, the Pittsburgh Post-Gazette printed a column titled "Stein vs. Hopkins": "Miss Stein is so positive of her importance, that she once challenged Miriam Hopkins to walk with her from Columbus Circle to Times Square - and offered to bet $\$ 500$, that she would get more requests for autographs than would the screen star." The fact that Stein was compared to Hopkins reflected the rise of the literary star - a figure constructed in relation to Hollywood's models of fame.

Despite Stein's playful show of superiority, she was willing to listen to Hopkins's advice on publicity and the media. Cerf reported that, after the interview, Hopkins congratulated Stein and asked her how much money she got from the radio station (Reminiscences, 23 Oct. 1967). "You mean they pay for this?" said Stein. Cerf quickly explained: “There's no pay for this sort of thing - it's the greatest publicity in the world to get a coast-to-coast prime time network interview." But Hopkins insisted that Stein should be paid, undoubtedly because putting a price on a radio performance would signal her rising celebrity. Following Hopkins's advice, Stein refused to be treated like an unknown writer grateful for any kind of attention. She told her publisher: "Miriam said I should get \$500. I won’t do it for less." While Cerf and his colleagues "could have got her on a lot of shows for nothing," they had to decline these offers. Stein's radio career was over after that, Cerf said. This anecdote shows the limits of the model of literary celebrity based on Hollywood. Unlike movie stars, writers could not reasonably expect to be paid for interviews that would create significant interest in their work. 


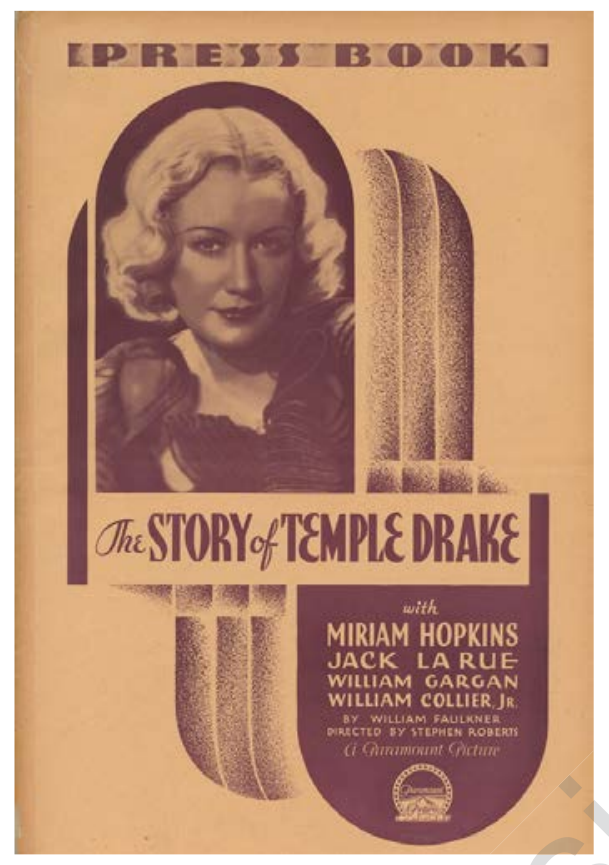

Figure 3: Press book, The Story of Temple Drake, 1933.

To celebrate Stein's arrival in America and the publication of Portraits and Prayers, Cerf and Klopfer gave a party at the offices of Random House. Publishers' Weekly reported that "Miss Stein and Miss Toklas are both very gracious guests, and the party was well attended by literary critics, authors, as well as the heads of many New York publishing houses" (10 Nov. 1934: 1754-55). ${ }^{25}$ The list of guests, preserved in the Random House archive, shows that Stein and Toklas were not greeted by a handful of "highbrows," but by a diverse mix of well-known figures from the literary and entertainment worlds. ${ }^{26}$ Many guests came from the "middlebrow" sphere, including Henry Seidel Canby (Saturday Review of Literature), Harry Scherman (Book-of-the-Month Club) and Irita Van Doren (New York Herald Tribune). Figures of the entertainment industry included Miriam Hopkins and journalists at Variety and Vanity Fair. Even tabloid newspapers such as the New York Daily Mirror and the Daily News were invited to send their staff to meet Stein and Toklas. ${ }^{27}$ Raymond Weaver, a professor at Columbia University, was one of only two academics invited at the party, and there were no literary critics working in little magazines and 
small-scale publishing enterprises. When choosing the list of guests, Cerf and Klopfer had privileged well-known critics at large-circulation newspapers and magazines.

In late 1934, Cerf sent out a press release, announcing that Three Lives was the best-selling book in the Modern Library series in November (Publishers' Weekly). "That has caused a great deal of comment," Cerf wrote to Stein (18 Dec. 1934). Having proved that even Stein's more experimental writings could sell, Cerf continued to apply the same marketing strategy to promote Lectures in America in spring 1935: he made fun of his author and insisted on the playfulness of her work. Stein's and Toklas's unusual physical appearance often featured in Cerf's jokes. Consider this example, reproduced in the Washington Post:

Miss Stein's American publisher is Random House on Fifty-seventh street. In the building they have an elevator operator who prides himself on being pervasively and unpretentiously percipient, in other words, of knowing exactly what to do with all the literary lions who drop in. When Miss Stein showed up the first time in her rough tweeds, towing the bewildered Alice B. Toklas, her secretary who answers to the name of "Lovely," the tactful operator did not carry them to the charming Random House on the fifth floor but insisted on pushing them both off at the second floor, the office of the Swedish Maids Employment Bureau. (Renaud)

Here, Stein's gender and unsophisticated appearance exclude her from the male area of "literary lions" and relegate her to the category of foreign servants. According to Cerf, Stein was "screaming with laughter.” Being mistaken for a cook “didn’t bother her a bit” (Reminiscences, 23 Oct. 1967). Stein's selfconfidence and willingness to laugh with others contributed to her image as a playful writer who did not take herself too seriously. Cerf's efforts to promote Stein were noticed (and perhaps resented) by other writers: the Surrealist author Philippe Soupault thus told Joyce that Cerf was so focused on Stein that he 
neglected Ulysses (J. Joyce to G. and H. Joyce, 19 March 1935). At the end of her tour, Stein had reportedly earned over ten thousand dollars (BC, Reminiscences, 23 Oct. 1967).

Paradoxically, the fact that Stein was not young, not elegant, and not willing to discuss serious subjects with "highbrows" contributed to her appeal. ${ }^{28}$ When Cerf stumbled across the fact that Stein was likeable, he did not waste a minute creating opportunities for her. Gertrude Stein became a star by being an anti-star, in a period when advertisements increasingly emphasized the sex appeal of young female writers. In 1945, after a glamorous picture of Kathleen Winsor appeared on the cover of Publishers' Weekly, Cerf arranged for a similar advertisement featuring a photograph of Stein and Toklas with the caption: Shucks, we've got glamour girls too! (Figure 5). The comparison between the twenty-five-yearold Winsor and the aging couple Stein/ Toklas was more than a joke. Macmillan had just launched Winsor's racy first novel Forever Amber with an advertising budget of nearly $\$ 27,000 .^{29}$ Winsor's moviestar-style portrait was reproduced on many formats - on dust jackets, advertisements, postcards, posters and newspaper covers. Likewise, Stein's image was an integral part of Cerf's strategy - appearing on the cloth of the cover of Portraits and Prayers, and on the dust jackets of Everybody's Autobiography and Wars I Have Seen (Figure 6).

Cerf and Stein's common fascination with celebrity contributed to their friendship, which lasted until her death in 1946. When Cerf married Sylvia Sidney only to realize that it was a tragic mistake (“At that time I was making, I remember, $\$ 200$ a week, and Sylvia was making $\$ 4,000$ a week" [Reminiscences, 19 Oct. 1967]), he could count on Stein for support through this difficult period. "Everybody talked about this great wonderful romance between the young publisher and the ravishing young star," Cerf later said. "There were articles in all the motion picture magazines. We were glamorized. And to have it end so quickly was embarrassing to both of us" (Reminiscences, 19 Oct. 1967). Stein, who had met Sidney over a lunch at Cerf's New York apartment, became worried about her publisher's well being. In January 1936, Cerf wrote to reassure her. Although he admitted that "it has all hurt a great deal and the publicity has been humiliating and cheap," he promised Stein that he would be 
better by the spring, at the time of his visit in France (BC to GS, 9 Jan. 1936). It was highly unusual for Cerf to confide his personal problems to an author, but he trusted Stein would understand the pitfalls of celebrity status.

The fact that Stein remained committed to the same publisher for the last twelve years of her life is highly significant. As this article has shown, Stein repeatedly expressed her gratitude to Cerf for publishing her difficult texts. In Everybody's Autobiography, she remembered the moment when "Bennett Cerf cabled for the rights of Three Lives for the Modern Library": "that was the beginning of a good deal because Bennett Cerf was to come to do everything" (ch. 3). Stein also wrote about her pleasure at being treated like a star when she came to America: "I never imagined that would happen to me to be a celebrity like that but it did and when it did I liked it" (Introduction). Although Cerf did not create Stein's fame, he was the first publisher to understand that her celebrity (and sales appeal) was compatible with the publication of her seemingly incomprehensible writings. While Alfred Harcourt seemed to be interested in Stein only when she wrote memoirs of her famous friends, Cerf had a much more nuanced understanding of her place in the marketplace. He worked to widen the audience for Stein's difficult writings, not only by using new media (radio, film) but also by reaching out to ordinary readers. Indeed, Cerf domesticated the criticism of Stein's writings by endorsing the role of the puzzled reader. It might have been difficult to market Stein as a "glamour girl," but it was definitely possible to present her as a charismatic writer that everybody should at least try to read. 

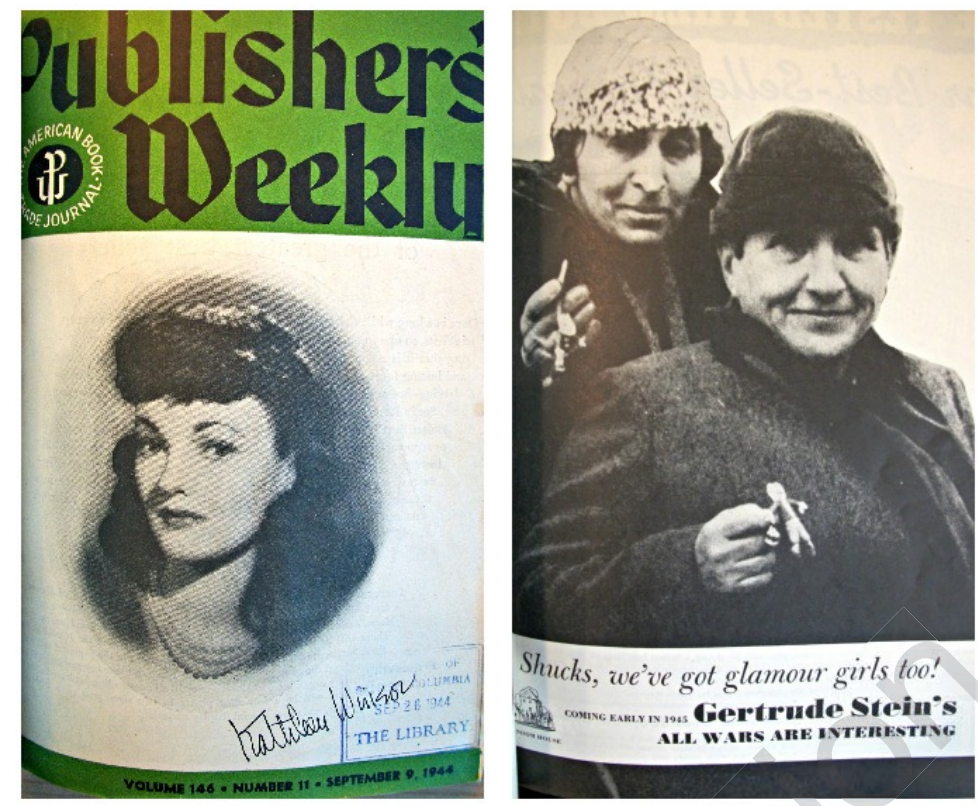

Figure 4: Publishers' Weekly, Cover, 9 Sept. 1944 (left) and Advertisement for Random House, 28 Oct. 1944: 1721 (right).
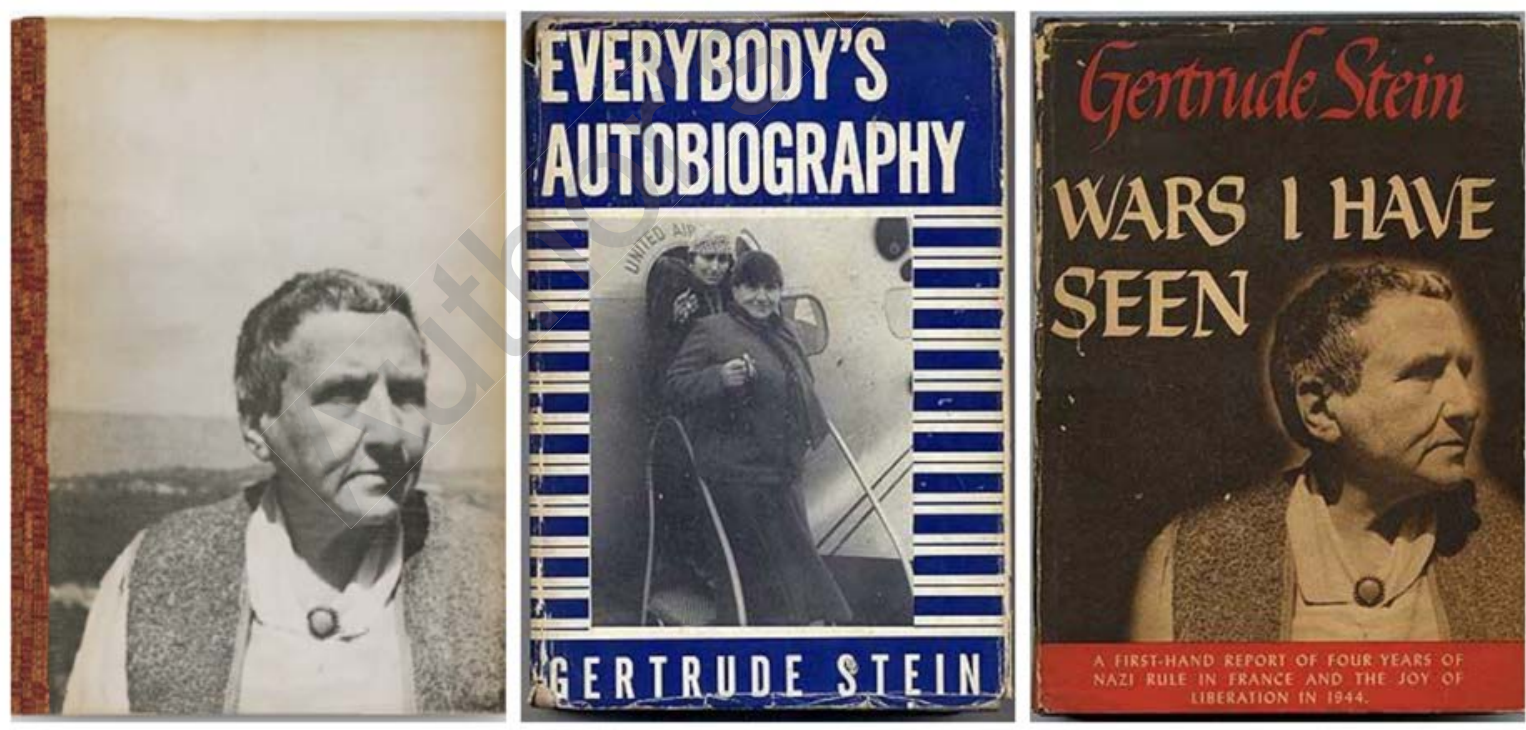

Figure 5: Cover, Portrait and Prayers (1934), Dust jackets, Everybody's Autobiography (1937) and

Wars I Have Seen (1945). 
${ }^{1}$ The Modern Library was created in New York in 1917, and specialized in often-controversial modern literature. For more information on the Modern Library, see Satterfield, Neavill, and Jaillant.

${ }^{2}$ For more information on Cerf, see his memoirs At Random. The book was published six years after his death and is based on interviews for the Columbia Oral History project, from which his widow, Phyllis Cerf Wagner, and Random House editor Albert Erskine shaped the text.

3 "Writers like James Joyce and Virginia Woolf were frequently mentioned by popular columnists and were very well-known public figures, even celebrities, in the 1920s and 1930s" (Leick 6).

${ }^{4}$ The term "communications circuit" was coined by Robert Darnton in his 1982 essay, "What is the History of Books?"

${ }^{5}$ On 16 May, Cerf wrote to Stein about reprinting Three Lives.

${ }^{6}$ I am grateful to Rod Rosenquist for his assistance.

${ }^{7}$ It seems that Bernard Faÿ was also in discussion with the Modern Library to write the introduction to Three Lives. See "Three Lives, Work by Gertrude Stein, to Be Issued Again." According to Ulla Dydo and William Rice, Faÿ was the author of this article, which claims that the Modern Library edition would appear with an introduction by himself $(545 \mathrm{n} 10)$.

8 "The six Three Lives have just come. . They are charmingly all blue ..." (GS to BC, 19 Oct. 1933).

${ }^{9}$ See also Butcher's review of The Making of Americans, in which she praises the Modern Library edition of Three Lives ("Book Presents Gertrude Stein as She Really Is").

${ }^{10}$ The other book reviewed was Bare Living, a novel on nudism by Elmer Davis and Guy Holt.

${ }^{11}$ See Turner 173-213.

12 The abridged edition was published in February 1934, the same month as the Random House edition of Four Saints in Three Acts. See The Making of Americans, Advertisement.

${ }^{13}$ This explains why Cerf tied the release of the reprinted edition of Three Lives to The Autobiography of Alice B. Toklas, a book widely reviewed in the mainstream press.

${ }^{14}$ Cerf later wrote that in the following four years after publication the trade edition of Ulysses "sold between 35,000 and 40,000 copies. In 1940, Ulysses was published as a Modern Library Giant, and in that edition has sold up to December 31, 1948 a total of 110,342 copies" (BC to Knopf, 14 April 1949).

15 "We made money on Gertrude, but she had a very limited audience" (BC, Reminiscences, 23 Oct. 1967).

16 "Carl [Van Vechten] assures me that your visit here this Fall is now certain" (BC to GS, 26 July 1934).

${ }^{17}$ Klopfer later joked that: "Gertie's lecture agent was a Miss Alice Toklas, who had the finest moustache on this side of the Atlantic. Now that she has taken it back to France, they are having a civil war over there" (Klopfer to Warren, 6 July 1936).

${ }^{18}$ Conrad thus notes: "Stein could have hardly generated more publicity had she contracted a public relations firm to popularize her in America" (225).

${ }^{19}$ For more information on the Pathé recording, see Meyer 106-7 n39.

${ }^{20}$ Inner flap of the dust jacket (Stein, The Geographical History of America).

${ }^{21}$ Inner flap of the dust jacket (Stein, Ida).

${ }^{22}$ See Cerf's account of his first meeting with his future wife: "I had told everybody that I must meet [the Hollywood actress] Sylvia Sidney, anybody that knew us both. And twice dinner dates were arranged, once with $\mathrm{Mr}$ Ernst Lubitsch and his wife... . Then came New Year's Eve, the end of 1934 going into 1935. .. I had a telephone call from a young man named Richard Halliday. Richard Halliday was in the story department of Paramount Pictures. ... And he said, "I'm bringing Sylvia Sidney" (Reminiscences, 19 Oct. 1967).

${ }^{23}$ For more information on Hopkins, see Callahan. For more on The Story of Temple Drake, see Ramsey and Barker. ${ }^{24}$ Time chose Hopkins for its cover on 27 May 1935, one year and a half after the Stein cover.

${ }^{25}$ The party took place on 31 Oct. 1934.

${ }^{26}$ Box 106A, RH.

${ }^{27}$ The Mirror, which Cerf described as a paper that "caters to readers of rather low mentality," had expressed interest in serializing Four Saints in Three Acts, before dropping the matter (BC to Bradley, 7 March 1934).

${ }^{28}$ New York Herald Tribune, 7 April 1935 (qtd in Mellow 409).

${ }^{29}$ Macmillan spent \$26,907.65 on advertising Forever Amber [1944-1946]. Box 104, Macmillan Company Records, Manuscripts and Archives Division, New York Public Lib. For more on Winsor and Macmillan, see Jaillant, "Subversive Middlebrow." 


\begin{abstract}
Abbreviations
CP: Bennett Cerf papers, Columbia Rare Book and Manuscript Lib., New York City.

RH: Random House archive, Columbia Rare Book and Manuscript Lib., New York City.

WB: William A. Bradley papers, Harry Ransom Center, University of Texas at Austin.
\end{abstract}

\title{
Works Cited
}

The Autobiography of Alice B. Toklas. Advertisement. New York Times 3 Sept. 1933: BR17. Print.

Barker, Deborah. "Moonshine and Magnolias: The Story of Temple Drake and the Birth of a Nation." Faulkner Journal 22.1/2 (2006): 140-75. Print.

Bishop, Edward. "Re: Covering Ulysses.” Joyce Studies Annual 5.5 (1994): 22-55. Print.

“Book Notes.” New York Times 22 Feb. 1934: 19. Print.

“Books and Authors.” New York Times 3 Sept. 1933: BR13. Print.

“Books: Stem’s Way.” Time Magazine 11 Sept. 1933. Web. 26 May 2014 $<$ http://www.time.com/time/magazine/article/0,9171,746058,00.html $>$.

Brace, Donald. Letter to William Bradley. 11 May 1934. Box 74, folder 4, WB.

Bradley, William. Letter to Bennett Cerf. 20 July 1933. Box 106A, RH.

---. Letter to Gertrude Stein. 19 July 1934. Box 59, folder 5, WB.

Burns, Edward, ed. The Letters of Gertrude Stein and Carl Van Vechten, 1913-1946. Vol. 1. New York: Columbia UP, 1986. Print.

Burns, Edward, and Ulla E. Dydo, eds. The Letters of Gertrude Stein and Thornton Wilder. New Haven: Yale UP, 1996. Print.

Butcher, Fanny. "Book Presents Gertrude Stein as She Really Is" [Review of The Making of Americans] Chicago Daily Tribune 10 Feb. 1934: 14. Print. 
---. "Gertrude Stein Writes a Book in Simple Style" [Review of The Autobiography of Alice B. Toklas]. Chicago Daily Tribune 2 Sept. 1933: 8. Print.

Callahan, Dan. “The Jezebel Swagger of Miriam Hopkins.” Sight \& Sound 22.12 (2012): 36-39. Print.

Cerf, Bennett. At Random: The Reminiscences of Bennett Cerf. New York: Random House, 1977. Print.

---. Diary. 27 May 1919. Box 11, CP.

---. Letter to Albert Boni. 11 May 1933. Box 106A, RH.

---. Letter to Gertrude Stein. 16 May 1933. Box 59, folder 3, WB.

---. Letter to Gertrude Stein. 23 Oct. 1933. Catalogued correspondence, RH.

---. Letter to Gertrude Stein. 21 Nov. 1933. Catalogued correspondence, RH.

---. Letter to Gertrude Stein. 26 July 1934. Box 344, RH.

---. Letter to Gertrude Stein. 18 Dec. 1934. Catalogued correspondence, RH.

---. Letter to Gertrude Stein. 9 Jan. 1936. Box 106A, RH.

---. Letter to Melrich Rosenberg. 16 Oct. 1934. Box 152, RH.

---. Letter to Pat Knopf. 14 April 1949. Box 13, RH.

---. Letter to Thornton Wilder. 19 Aug. 1936. Box 106A, RH.

---. Letter to Tom Coward. 15 Oct. 1942. Box 136, RH.

---. Letter to William Bradley. 16 June 1933. Box 105, folder 6, WB.

---. Letter to William Bradley. 7 March 1934. Box 106A, RH.

---. Reminiscences. Oral History Research Office, Columbia University Lib.

Conrad, Bryce. "Gertrude Stein in the American Marketplace.” Journal of Modern Literature 19.2 (1995): 215-33. Print.

Darnton, Robert. "What is the History of Books?” Daedalus 111.3 (1982): 65-83. Print.

Drew, Ned, and Paul Spencer Sternberger. By its Cover: Modern American Book Cover Design. New York: Princeton Architectural P, 2005. Print.

Dydo, Ulla E., and William Rice. Gertrude Stein: The Language that Rises: 1923-1934. Evanston, Ill: Northwestern UP, 2003. Print. 
Fitzgerald, F. Scott. Letter to Bennett Cerf. 20 Nov. 1934. Catalogued correspondence, RH.

Gilmer, Walker. Horace Liveright: Publisher of the Twenties. New York: D. Lewis, 1970. Print.

Glass, Loren. Authors Inc.: Literary Celebrity in the Modern United States, 1880-1980. New York: New York UP, 2004. Print.

Goldman, Jonathan. Modernism is the Literature of Celebrity. Austin: U of Texas P, 2011. Print.

Hammill, Faye. Women, Celebrity, and Literary Culture between the Wars. Austin: U of Texas P, 2007. Print.

Hitchcock, H. Wiley, and Charles Fussell. Introduction. Four Saints in Three Acts, by Virgil Thomson and Gertrude Stein. Middleton: A-R Editions, 2008. xiii-xiv. Print.

Hubbell, Lindley Williams. Letter to Gertrude Stein. 11 May 1933. Box 59, folder 3, WB.

Jaffe, Aaron. Modernism and the Culture of Celebrity. Cambridge: Cambridge UP, 2005. Print.

Jaillant, Lise. "Canonical in the 1930s: Willa Cather's Death Comes for the Archbishop in the Modern Library Series." Studies in the Novel 45.3 (2013): 476-99. Print.

---. “Modernism, Middlebrow and the Literary Canon in the Modern Library Series, 1917-1955." Diss. U. of British Columbia, 2013. Print.

---. "Subversive Middlebrow: The Campaigns to Ban Kathleen Winsor's Forever Amber in the US and Canada." International Journal of Canadian Studies 48 (2014): 33-52. Print.

J. J. Little and Ives Co. Letter to Emanuel Harper. 7 April 1934. Box 106A, RH.

Joyce, James. Letter to George and Helen Joyce. 19 March 1935. Letters of James Joyce. Ed. Richard Ellmann. Vol. 3. London: Faber \& Faber, 1966. 351. Print.

Klopfer, Donald. Letter to Dale Warren. 29 June 1936. Box 124, RH.

---. Letter to Dale Warren. 6 July 1936. Box 124, RH.

---. Letter to Ernest Reichl. 4 Feb. 1935. Box 106A, RH.

---. Letter to Melrich Rosenberg. 7 Feb. 1934. Box 152, RH.

Leick, Karen. Gertrude Stein and the Making of an American Celebrity. New York: Routledge, 2009. Print. 
The Making of Americans. Advertisement. Publishers' Weekly 13 Jan. 1934: 126. Print.

Mellow, James R. Charmed Circle: Gertrude Stein \& Company. New York: Praeger, 1974. Print.

Meyer, Steven. "Gertrude Stein." The Cambridge History of Literary Criticism. Eds. A. Walton Litz, Louis Menand, and Lawrence Rainey. Vol. 7. Cambridge: Cambridge UP, 2000. 93-121. Print.

Modern Library (a). Advertisement. New Republic 11 Oct. 1933: v. Print.

Modern Library (b). Advertisement. New York Times 5 Aug. 1934: BR13. Print.

Neavill, Gordon B. "From Printing History to History of the Book." Canadian Review of Comparative Literature/ Revue Canadienne de Littérature Comparée 23.1 (1996): 225-37. Print.

---. “The Modern Library Series.” Diss. U. of Chicago, 1984. Print.

---. “The Modern Library Series and American Cultural Life.” Journal of Library History 16.2 (1981): 241-52. Print.

Publishers' Weekly 22 Dec. 1934: 2215. Print.

Ramsey, D. Matthew. "'Lifting the Fog': Faulkners, Reputations and The Story of Temple Drake." Faulkner Journal 16.1-2 (2000): 7-33. Print.

Random House. Advertisement. New York Times 9 March 1934: 17. Print.

Renaud, Ralph E. “Heigh-o The Merri-o, Farmer's in New York.” Washington Post 19 May 1935: B7. Print.

Rosenquist, Rod. "Modernism, Celebrity and the Public Personality." Literature Compass 10.5 (2013): 437-48. Print.

Satterfield, Jay. The World's Best Books: Taste, Culture, and the Modern Library. Amherst: U of Massachusetts P, 2002. Print.

Saunders, Allen. "Life Among the Nudists and An Early Work by Gertrude Stein Considered." Toledo News-Bee 17 Oct. 1933: 8. Print.

Stein, Gertrude. The Autobiography of Alice B. Toklas. Harmondsworth: Penguin, 1966. Print.

---. Everybody's Autobiography. New York: Vintage, 1973. Kindle file.

--- Ida. New York: Random House, 1941. Print. 
---. The Geographical History of America. New York: Random House, 1936. Print.

---. Letter to Bennett Cerf. 19 Oct. 1933. Box 2, CP.

---. Letter to Carl Van Vechten. [July 1933?]. Burns 269.

---. Letter to Carl Van Vechten. 11 Oct. 1933. Burns 279.

---. Letter to Carl Van Vechten and Fania Marinoff Van Vechten. 4 Nov. 1933. Burns 284.

---. Letter to William Bradley. [Aug.] 1933. Box 59, folder 3, WB.

---. “A Radio Interview.” Paris Review 116 (1990): 85-97. Print.

“Stein vs. Hopkins." Pittsburgh Post-Gazette 11 June 1940: 10. Print.

“Three Lives, Work by Gertrude Stein, to Be Issued Again.” Chicago Daily Tribune 19 Aug. 1933: 8. Print.

Turner, Catherine. Marketing Modernism between the Two World Wars. Amherst: U of Massachusetts P, 2003. Print.

Van Vechten, Carl. Introduction. Three Lives, by Gertrude Stein. New York: Modern Library, 1933. v-xi. Print.

Wilson, Edmund. "27 rue de Fleurus.” New Republic 11 Oct. 1933: 246-47. Print. 